\title{
Hearing Aid Selection: Closed- versus Open-canal Fitting Hearing Aids
}

\author{
Sangyeon Lee ${ }^{1}$, Soo Hee Oh ${ }^{2,3}$, Kyoungwon Lee ${ }^{2,3}$ \\ ${ }^{1}$ Division of Speech Pathology and Audiology, College of Natural Sciences, Hallym University, Chuncheon, Korea \\ ${ }^{2}$ HUGS Center for Hearing and Speech Research, Seoul, Korea \\ ${ }^{3}$ Department of Audiology and Speech-Language Pathology, Hallym University of Graduate Studies, Seoul, Korea
}

Received: July 26, 2021

Revised: August 30, 2021

Accepted: September 13, 2021

Correspondence:

Kyoungwon Lee, $\mathrm{PhD}$

Department of Audiology and

Speech-Language Pathology,

Hallym University of Graduate

Studies, 427 Yeoksam-ro,

Gangnam-gu, Seoul 06197, Korea

Tel: $+82-2-2051-4951$

Fax: $+82-2-3453-6618$

E-mail: hearing1004@naver.com
To select hearing aid is an essential process for successful hearing rehabilitation. The purpose of this study is to review hearing aid selection considerations between receiver in-the-canal (RIC) and custom hearing aid (CHA) in order to guide appropriate selection of the hearing aid. This study discussed three key factors in the hearing aid selection including physical, acoustic and electroacoustic characteristics and other aspects. Advantages of RIC types are comfort to wear, reduction of the occlusion effect, presence of directional microphones, on-site fit, easy connectivity with other devices, and use of rechargeable batteries. On the other hand, the CHA types have their advantage in terms of being comfort to wear with masks, proper insertion and placement, reduction of the acoustic feedback, good approximation of frequency response curve, improvement of speech in noise perception, expanded hearing aid candidacy with varying hearing thresholds, and easy telephone use. We concluded that appropriate selection of the hearing aid would contribute to successful hearing rehabilitation, if considering physical, psycho-social, and acoustical characteristics.

Key Words: Hearing aid, Open-canal fitting, Closed-canal fitting, Receiver in-the-canal, Custom hearing aid.

\section{INTRODUCTION}

보청기는 전기음향파라미터(electroacoustic parameter)의 조절 방법에 따라 비프로그램(non-programmable)과 프로그 램(programmable), 입출력함수곡선(input output function curve)의 특성에 따라 선형(linear type)과 비선형(nonlinear type), 신호처리 방식에 따라 아날로그(analog)와 디지 털(digital), 채널의 수에 따라 단채널(single channel)과 다채 널(multi-channel) 보청기로 구분할 수 있다. 또한 착용 시 보 청기몸체(hearing aid shell) 또는 이어몰드(earmold)가 외이 도를 폐쇄하는 정도에 따라서 외이도폐쇄적합(closed-canal fitting)과 외이도개방적합(open-canal fitting) 보청기로 구분 할 수 있다.

외이도폐쇄적합 보청기는 보청기 자체를 외이도 내에 삽입 하는 것으로 난청인의 귀에서 채취한 귓본을 토대로 제작하는

(c) This is an Open Access article distributed under the terms of the Creative Commons Attribution Non-Commercial License (https://creativecommons.org/ licenses/by-nc/4.0) which permits unrestricted non-commercial use, distribution, and reproduction in any medium, provided the original work is properly cited. 갑개보청기(in-the-ear, ITE), 외이도보청기(in-the-canal, ITC), 고막보청기(completely in-the-canal, CIC) 등의 귓 속형(custom hearing aid, $\mathrm{CHA}$ ) 그리고 보청기몸체를 귓바 퀴 뒤에 착용한 후 증폭음을 이어몰드튜브 또는 전선을 통해 외 이도 내에 삽입한 이어몰드 또는 수화기로 전달하는 귀걸이형 (behind-the-ear, BTE) 보청기가 있다. 외이도폐쇄적합형의 보청기는 보청기몸체 또는 이어몰드에 음향임피던스(acoustic impedance)가 높은 작은 직경의 환기구(vent)를 사용하기 때 문에 외이도를 폐쇄하는 형태이다. 이에 반해 외이도개방적합 보 청기는 음향전달 임피던스를 낮추기 위해 보청기몸체 또는 이어 몰드에 ipsilateral routing of signal (IROS)과 같이 직경이 큰 환기구를 설치하는 것으로 외이도를 개방하여 고막 부근의 음압 레벨(sound pressure level)을 외이도 밖으로의 배출을 용이하 게 하는 CHA 또는 BTE 보청기를 들 수 있다(Caporali et al., 2019; Prakash et al., 2013). 그리고 BTE의 형태로 수화기가 외이도 내에 위치하는 receiver-in-the-ear canal (RITE)과 보청기몸체에 위치하는 receiver-in-the-aid (RITA) 보청기는 외이도 내에 위치한 이어돔(ear dome)의 큰 환기구로 인해 외이 
도를 개방하는 대표적인 외이도개방적합 보청기로 알려져 있다 (Dillon, 2012). 본고에서는 최근의 문헌(Caporali et al., 2019) 과 시장의 동향을 감안하여 RITE 대신 receiver in-the-canal (RIC)이라는 용어를 사용하였다.

2000년대 중반부터 본격적으로 판매를 시작한 RIC 보청 기는 미관, 편안한 착용감, 방향마이크로폰의 내장, 폐쇄효 과(occlusion effect) 및 음질의 개선 등 외이도폐쇄적합 보 청기에서 구현할 수 없는 다양한 장점이 있다(Gnewikow \& Moss, 2006; Kochkin, 2011; MacKenzie, 2006; Prakash et al., 2013; Winkler et al., 2016). 이에 RIC 보청기의 판 매 비중은 북미 지역에서 2009년 24\%, 2014년 58\%, 2017년 69\%로 급격히 증가하였다(Sim \& Kim, 2019). The Hearing Review(2021)는 RIC 보청기 판매비율의 증가 원인을 미관, 편 안한 착용감, 소음 하 어음청취능력의 개선 등으로 보고하였다.

하지만 RIC는 The Hearing Review(2021)에서 보고한 장점 이 있지만 단점 또한 존재한다. 이를 살펴보면 Jo et al.(2021)의 연구에서는 $0.75 \mathrm{kHz}$ 이하의 주파수에서 RIC의 실이삽입이득 은 외이도폐쇄적합에 비해 $5 \mathrm{~dB}$ 정도 낮게 나타나며, Park and Lee(2019), Prakash et al.(2013)은 외이도의 직경이 작은 경우 폐쇄효과를 해결하는 데 어려움이 있다고 하였다. 그리고 Aazh et al.(2012), Hoen and Fabry(2007)는 직경이 큰 환기구로 인 해 고주파수, 특히 $4.0 \mathrm{kHz}$ 부근의 주파수 대역에서 음향피드 백으로 인해 충분한 이득을 제시하기가 어려울 수가 있다고 하 였다. 그리고 Sanders et al.(2015)의 연구에서는 현재 보청기 의 조절에 사용하고 있는 보청기적합소프트웨어의 National Acoustic Laboratories-non-linear 2 (NAL-NL2)의 작은 (soft) 그리고 보통(moderate) 크기에 대한 이득은 $3.0 \mathrm{kHz}$ 이 상의 주파수에서 원래의 NAL-NL2에 비해 낮게 나타난다고 보 고하였다. 이에 Winkler et al.(2016)은 중고주파수 대역의 청 력역치(hearing threshold level)가 $70 \mathrm{~dB} \mathrm{HL}$ 이하인 경우에 만 개방형 돔을 사용하는 RIC 보청기의 사용이 효과적이라고 하 였다.

위에서 기술한 RIC의 단점이 있음에도 불구하고 현재 RIC의 판매량은 국내외에서 크게 증가하고 있는 추세다. 하지만 외이도 개방 및 외이도폐쇄적합 보청기를 선택하기 위해서는 상기에서 기술한 미관, 편안한 착용감, 방향마이크로폰의 내장, 폐쇄효과 및 음질의 개선 외에 난청인의 신체, 보청기의 형태에 따른 음향 및 전기음향적 특성 등 다양한 요소를 고려해야 한다. 이에 본 연구에서는 RIC와 CHA 보청기의 선택에 도움을 주기 위해 두 보청기의 특징을 신체 및 보청기의 착용, 음향 및 전기음향적 특 성 그리고 기타 고려사항으로 구분하여 내용을 확인하고, 장단 점을 정리하였다.

\section{METHODS}

본 연구에서는 외이도폐쇄적합 보청기인 $\mathrm{CHA}$ 와 외이도개방 적합 보청기인 RIC의 효과적인 선택을 위해 각 보청기의 특징을 확인하고, 주요 사항을 Appendix로 정리하여 첨부하였다. 확인 한 주요 내용은 첫째, 미관, 작은 외이도의 크기, 보청기의 착용 등 신체적인 특성과 보청기의 착용, 둘째, 폐쇄효과, 음향피드백, 주파수반응곡선, 착용 가능한 청력역치, 소음 하 어음청취능력, 방향마이크로폰 등 전기음향적 특성, 마지막으로 제조 기간 및 조절, 전화의 사용, 다른 기기와의 연결, 충전식 전지 등 기타 고 려사항이었다.

\section{DISCUSSIONS}

\section{신체적인 특성(physical characteristics)}

\section{미관(cosmetics)}

RIC 보청기는 BTE의 한 종류로 집적회로(integrated circuit) 기술의 발전에 따라 크기가 눈에 띄게 작아졌으며, 수 화기에서 발생한 증폭 음향을 이어팁으로 전달할 때 튜브가 아 닌 직경이 가는 전선을 사용하기 때문에 미관적으로 우수하다 (Kochkin, 2011). 그리고 외이도개방적합 보청기의 초기 버전인 RITA는 보청기몸체에 내장된 수화기에서 튜브를 사용하여 증 폭음을 이어몰드와 고막으로 전달하였지만, RIC 보청기는 증폭 한 전기신호를 가느다란 전선을 통하여 외이도 내에 삽입한 수화 기에 전달한 다음 변환된 증폭음향을 고막으로 전달하기 때문 에 미적인 측면에서 우수하다고 할 수 있다. 반면에 대부분 외이 도폐쇄형 보청기인 CHA 또한 좋은 미관을 고려하기 위해 ITE, ITC, CIC 보청기로 발전하였으며, 최근에는 타인의 눈에 띄 는 것을 고려하여 더욱 작은 형태인 초고막(invisible in-thecanal, IIC) 보청기를 개발하여 사용자들의 미적인 측면에 있어 서 만족감을 주고 있다.

\section{작은 외이도 크기(small size of ear canal)}

보청기 착용 시 수화기를 일정하고 정확한 위치에 삽입하는 것 은 매우 중요하다. 그 이유는 수화기의 삽입 깊이에 따라 고막 부 근의 잔여용적이 달라지기 때문에 고막 부근에서의 음압 또는 이득이 달라지기 때문이다(Munro \& Davis, 2003). 일반적인 형태와 직경의 외이도는 RIC 보청기의 수화기를 포함한 이어돔 또는 $\mathrm{CHA}$ 보청기를 삽입하는 데 특별한 문제는 없다. 그러나 지 나치게 작은 직경의 외이도는 RIC 보청기의 수화기를 일정한 위 치에 삽입하는 데 어려움이 있어서 일정한 이득 또는 음압의 제 공이 어려울 수 있다. 또한 이어돔의 일그러짐으로 인해 환기구 
가 변형되어 환기구가 작아짐으로 인해 착용감의 저하 및 폐쇄 효과를 해결하는 데 어려움이 있을 수 있다(Park \& Lee, 2019; Prakash et al., 2013). CHA 보청기 역시 작은 직경의 외이도 는 폐쇄효과를 해결하는 데 어려움이 있을 수 있지만, 보청기를 깊게 그리고 꽉 차게 삽입하여 해결이 가능하다(Park \& Lee, 2019).

\section{보청기 착용(hearing aid wearing)}

$\mathrm{RIC}$ 보청기는 크기가 작아지고 수화기와 연결하는 튜브 대신 가느다란 전선을 사용함으로 인해 착용감이 좋아졌다. 하지만 최근 coronavirus disease-19 (COVID19) 대유행으로 인해 마 스크의 착용이 일상화되었는데 RIC의 경우 보청기몸체를 착용 하는 위치와 마스크 줄을 거는 위치가 같기 때문에 보청기를 착 용하고 벗을 때 불편함이 있을 수 있다. 반면에 $\mathrm{CHA}$ 보청기는 갑개(concha) 또는 외이도 내에 위치함으로 인해 마스크 착용 에 방해가 되지 않으며, 정확한 귓본의 채취와 스캔 그리고 3차 원 프린터 기법을 이용한 제작기술의 발전으로 편안한 착용감을 가능케 하였다.

$\mathrm{RIC}$ 와 $\mathrm{CHA}$ 보청기의 선택 시 신체적인 고려사항을 미관, 작 은 외이도의 크기, 보청기의 착용으로 구분하여 Appendix 1에 정리하였다.

\section{음향 및 전기음향적 특성(acoustic \& electroacoustic characteristics)}

\section{폐쇄효과(occlusion effect)}

폐쇄효과는 Figure 1과 같이 외이도 내로 전달되어 재생성된 성대의 진동이 보청기 외부로 배출되지 못하고 고막으로 전달될 때 주로 발생한다(Dillon, 2012). 이 경우 개방형 이어돔을 사용 하는 RIC 보청기는 큰 환기구의 낮은 음향임피던스로 인해 재생 성된 음향을 쉽게 외부로 배출하여 폐쇄효과의 해결에 효과적인
것으로 잘 알려져 있다(Caporali et al., 2019; Prakash et al., 2013; Winkler et al., 2016). 하지만 폐쇄효과와 관련하여 RIC 보청기는 몇 가지 문제점을 가지고 있다. 첫째는 협착으로 인한 타원형의 형태 또는 작은 직경을 가진 외이도의 경우는 수화기 주변의 이어돔이 일그러져서 고막 부근의 증폭음향의 배출을 방 해할 수 있다. 두 번째, 청력역치의 증가로 인해 개방형이 아닌 폐 쇄(closed) 또는 이중(double) 돔을 사용하는 경우 고막 부근의 음압을 외이도 밖으로 배출하지 못해서 폐쇄효과가 오히려 증가 할 수 있다(Park \& Lee, 2019). 반면에 CHA 보청기는 외이도의 모양을 나타내는 귓본(ear impression)을 채취하여 보청기를 제작하기 때문에 외이도 협착으로 인해 음출구(sound outlet) 의 일그러짐은 발생하지 않는다. 그리고 외이도의 작은 공간적인 문제로 큰 직경의 환기구의 제작이 불가능하여 폐쇄효과의 해결 에 어려움이 있지만 보청기에서 외이도에 해당하는 부분을 깊게 그리고 외이도와 밀착되도록 삽입하여 폐쇄효과의 효과적인 해 결이 가능하다(Dillon, 2012; Park \& Lee, 2019).

\section{음향피드백(acoustic feedback)}

보청기에서의 음향피드백은 다양한 발생 원인이 있지만 증폭 음이 마이크로폰으로 재유입되는 양 그리고 수화기와 마이크로 폰 간의 간격을 주요 원인으로 들 수 있다(Dillon, 2012; Hoen \& Fabry, 2007). 음향피드백과 관련하여 RIC와 CHA의 형태 적인 특징을 살펴보면 $\mathrm{RIC}$ 는 큰 직경의 개방형 돔, $\mathrm{CHA}$ 는 수화 기와 환기구 간의 간격이 가까움으로 인해 음향피드백의 발생확 률이 높아진다. 결국 RIC 보청기는 음향피드백제어시스템(antifeedback system)을 작동한다 하더라도 제조사의 보청기적 합 소프트웨어에서 음향피드백 방지를 위해 이득을 낮게 설정하 기 때문에 $4 \mathrm{kHz}$ 부근의 이득을 보청기적합공식(예; NAL-NL1) 에 근접하도록 제공하는 데 어려움이 있을 수 있다(Aazh et al., 2012; Chalupper \& Kasanmascheff, 2008). 따라서 RIC 보 청기는 중고주파수 대역의 청력역치가 $70 \mathrm{~dB} \mathrm{HL}$ 이상인 경우는

A

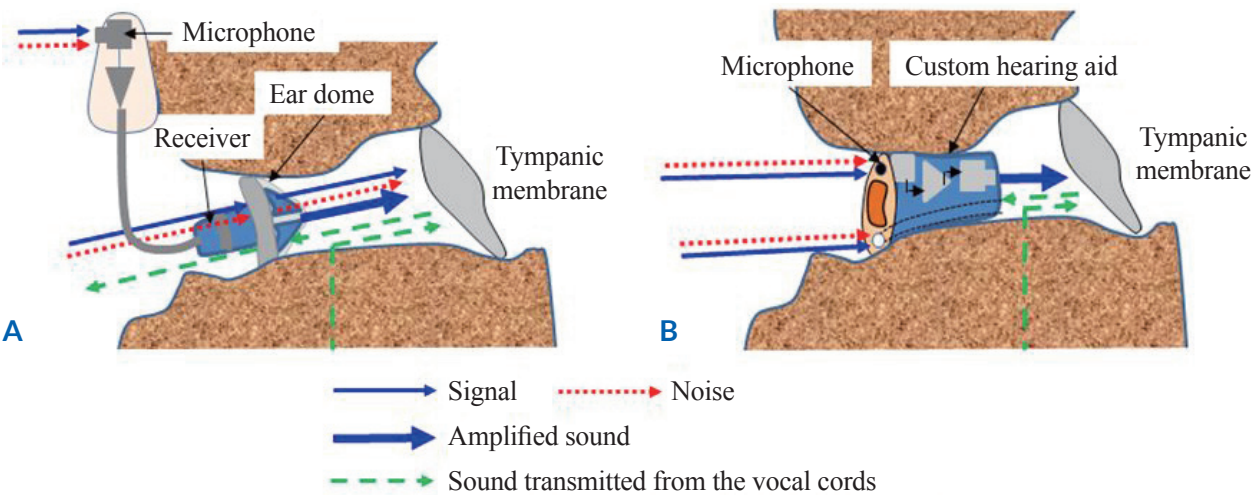

Figure 1. The path of sound to the eardrum in receiver in-the-canal (A) and custom hearing aid (B). 
사용에 제한이 있을 수 있다(Winkler et al., 2016). 수화기와 환기구 간의 간격이 가까운 $\mathrm{CHA}$ 보청기의 경우는 작은 직경의 환기구 그리고 정확한 귓본의 채취를 통해 외이도를 정확하게 밀 폐함으로 인해 음향피드백의 발생확률을 낮출 수 있다(Dillon, 2012).

\section{주파수반응곡선(frequency response curve)}

RIC 보청기는 수화기를 외이도 내에 삽입하기 때문에 주파수 반응곡선은 $\mathrm{CHA}$ 와 비슷하게 구현할 수 있다. 하지만 RIC는 개 방 돔의 큰 환기구로 인해 고막 부근의 음압을 외이도 밖으로 과 다하게 배출하며(Groth \& Mecklenburger, 2011; Jo et al., 2021; Kuk \& Baekgaard, 2008; Teie, 2009), 음향피드백시 스템의 작동으로 인해 $2.0 \mathrm{kHz}$ 이상 주파수 대역의 이득이 낮 게 나타날 수 있다. 따라서 RIC의 주파수반응곡선을 보청기적합 공식에서 산출한 값에 근접하도록 제공하는 데 어려움이 있다 (Chalupper \& Kasanmascheff, 2008). CHA와 다르게 나타 나는 RIC 보청기의 주파수반응곡선에 따른 효과에 대한 연구는 부족하지만 주파수반응곡선의 차이는 보청기의 음질, 조용한 곳 또는 소음 하에서의 어음인지도, 만족도 등에 영항을 줄 수 있을 것으로 보인다.

\section{소음 하 어음청취(speech perception in noise)}

난청인의 어음청취능력은 소음에 의해 많은 영향을 받는 것 은 잘 알려져 있다(Başkent, 2006; Needleman \& Crandell, 1995). Figure 1은 보청기 외부의 어음신호와 소음이 보청기 를 통해 고막으로 전달되는 과정을 나타낸 것이다. Figure $1 \mathrm{~A}$ 의 RIC 보청기에서 외부의 어음신호와 소음이 고막으로 전달되는 과정과 음압의 변화에 대해서 살펴보면 첫째, 마이크로폰에서 전기신호로 변환된 다음 보청기의 증폭기에서 증폭된 후 다시 음향신호로 변환되어 고막으로 전달된다. 이때 어음신호는 청력 역치의 정도에 알맞게 증폭되며, 소음은 적절한 음압레벨로 조 절된다(주로 감소). 둘째, 마이크로폰으로 유입된 어음신호와 소 음은 큰 직경의 환기구로 인해 원래의 음압레벨을 유지한 채 이 어돔을 통해 고막으로 전달된다. 이 경우 환기구로 유입된 어음 신호는 증폭신호와 비교하였을 때 너무 작기 때문에 무시할 수 있다. 하지만 환기구로 유입된 저주파수 또는 큰 음압레벨의 소 음은 에너지의 감소 없이 고막으로 전달되기 때문에 소음 하에 서 어음의 인지에 영향을 줄 수 있다. 특히 저주파수 대역의 청력 역치가 나쁘지 않은 경우 저주파수 스펙트럼을 가진 소음은 어 음의 인지에 나쁜 영향을 줄 수 있다. 반면, Figure $1 \mathrm{~B}$ 는 $\mathrm{CHA}$ 보청기의 일종으로 어음신호와 소음은 대부분 마이크로폰과 보 청기의 증폭기에서 적절한 음압레벨로 조절된 다음 고막으로 전 달된다. 그리고 환기구로 전달된 어음신호와 소음레벨은 작은 직
경의 환기구로 인해 크게 감소한다. 결국 환기구를 통해 고막으 로 전달된 소음레벨은 RIC에 비해 CHA에서 크게 감소하여 소 음에 의한 영향은 $\mathrm{CHA}$ 에서 적게 나타난다.

이를 종합해 보면 $\mathrm{CHA}$ 보청기에 비해 환기구의 직경이 커 서 외이도를 개방하는 RIC 보청기는 고막으로 전달되는 소음 의 양이 많기 때문에 소음 하에서 난청인의 어음인지도가 저하 될 우려가 있다. 이를 뒷받침하는 연구를 살펴보면 Froehlich \& Littmann(2019)은 소음 하에서 이어몰드의 종류에 따른 어음 인지능력을 확인하였는데, 문장 $50 \%$ 를 인지하기 위한 신호대잡 음비는 외이도폐쇄형 이어몰드가 외이도개방형 돔에 비해서 낮 게 나타났다고 보고하였다. 그리고 Froehlich et al.(2019)은 조 용한 곳 및 잡음 하에서의 문장인지도는 외이도개방형에 비해 외이도폐쇄형 이어몰드가 더 높게 나타난다고 보고하여 잡음 하 에서의 어음인지는 RIC에 비해 CHA가 더 효과적임을 알 수 있 다.

\section{방향마이크로폰(directional microphone)}

방향마이크로폰은 특정 방향 또는 잡음이 유입되는 방향 의 음압레벨을 줄여서(cut off) 신호대잡음비(signal-to-noise ratio)를 개선하고 다양한 상황에서의 어음청취능력을 개선하는 데 효과적이다. 그러나 방향마이크로폰을 구현하기 위해서는 한 개 또는 두 개 이상의 마이크로폰에서 음입구(sound inlet) 간 의 거리를 적당한 간격으로 유지하도록 해야 가능하다(Dillon, 2012). RIC는 음입구를 보청기몸체에 설치하거나 보청기몸체와 수화기 부근에 설치할 수 있어서 방향마이크로폰의 구현이 가능 하다(Anderson \& Van Doorn, 2011). 하지만 CHA 보청기의 경우 ITE, ITC를 제외한 CIC 또는 IIC에서는 마이크로폰의 음 입구 간의 간격 확보가 불가능하여 방향마이크로폰의 내장이 불 가능하다. 그렇지만 $\mathrm{CHA}$ 의 경우 마이크로폰이 외이도 입구 부 근에 위치하기 때문에 귓바퀴로 인한 방향마이크로폰의 특성을 구현할 수 있어서 뒤편 $\left(180^{\circ}\right)$ 에서 유입되는 소음레벨을 어느 정 도 줄일 수는 있다.

\section{적용 가능한 청력역치(applicable hearing threshold level)}

수화기와 마이크로폰의 간격이 일정할 때 환기구의 직경이 증 가하면 음향피드백의 발생확률이 높아지기 때문에 고막에 제시 할 수 있는 이득은 낮아진다(Hoen \& Fabry, 2007). 이로 인해 Kuk and Baekgaard(2008)는 RIC 보청기는 심한 청력손실자 가 사용하기에는 제한이 있으며, 청력역치가 높아지면 사용할 수 있는 환기구의 직경은 작아야 한다고 보고하였다. 물론 RIC 보 청기의 경우 청력역치가 증가하면 폐쇄형 또는 이중 돔을 사용할 수 있다. 하지만 환기구가 없거나 작아지는 효과로 인해 고막 부 근의 음압을 외이도 밖으로 원활하게 배출하지 못하며, 이어돔 
을 고막 가까이 삽입하기가 어려워서 폐쇄효과가 증가할 수 있다 (Park \& Lee, 2019). Winkler et al.(2016) 또한 RIC 보청기의 경우 중고주파수 대역의 청력역치가 $70 \mathrm{~dB} \mathrm{HL}$ 이상인 경우는 사용에 제한이 있을 수 있다고 보고하였다. 결국 청력손실이 심 한 경우 충분한 이득을 제공하기 위해서는 개방형 돔을 사용하 는 RIC보다는 외이도폐쇄적합형인 $\mathrm{CHA}$ 보청기가 효과적이라 할 수 있다.

RIC와 CHA 보청기의 선택 시 음향 및 전기음향적 고려사 항을 폐쇄효과, 음향피드백, 주파수반응곡선, 소음 하 어음청 취능력, 방향마이크로폰, 적용 가능한 청력역치로 구분하여 Appendix 2에 정리하였다.

\section{기타 고려사항(other considerations)}

\section{제조 기간 및 즉각적 조절(production period \& on-site fit)}

RIC 보청기는 기성품으로 이어돔을 다양하게 갖추고 있다면 별도의 제작 기간이 필요 없다. 따라서 컴퓨터에 내장된 보청기 적합 소프트웨어와 연결하여 즉시 착용, 조절 및 판매가 가능하 다. 하지만 $\mathrm{CHA}$ 보청기의 경우는 접수, 제작 및 발송을 위해 5 일 내외의 기간이 필요하여 즉시 착용, 조절 및 판매가 불가능하다.

\section{다른 기기와의 연결(connection to other devices)}

블루투스(bluetooth), near-field magnetic induction (NFMI), 2.4-GHz industrial scientific medical (ISM) 대역, 900-MHz ISM 대역 등의 무선주파수 이용하여 보청기를 스마 트폰 등 다른 음향 또는 통신기기와 연결하기 위해서는 신호를 전달하기 위한 안테나가 필요하다(Galster, 2010). BTE의 한 형 태로 귓바퀴 뒤에 착용하는 RIC 보청기는 일정한 형태와 용적 을 갖기 때문에 신호의 전달을 위한 무선 안테나의 내장이 가능 하여 다른 기기와의 연결이 용이하다. 반면에 CHA 보청기는 사 용자마다 보청기몸체의 형태 및 용적이 다르기 때문에 내부 공간 의 확보가 어려워 다른 기기와의 연결이 어렵다. 최근 일부 ITE, ITC 및 CIC 보청기의 경우 무선 안테나를 내장하기 시작했지만 제품의 크기가 커질 우려가 있다. 하지만 가까운 미래에는 무선 안테나를 내장함에도 그 크기를 현저하게 줄일 수 있을 것으로 생각한다.

\section{전화기의 사용(phone usages)}

RIC 보청기는 마이크로폰이 귓바퀴 뒤에 착용한 보청기몸체 에 위치하기 때문에 전화 통화 시 전화기의 수화기를 외이도 입 구가 아닌 마이크로폰과 같은 곳에 위치하도록 해야 한다. 하지 만 $\mathrm{CHA}$ 보청기의 경우는 음향피드백이 발생하지 않는다면 건청 인과 비슷한 형태로 전화기의 수화기를 외이도 입구에 위치하도
록 하여 전화 통화가 가능하다.

\section{충전식 전지(rechargeable battery)}

RIC 보청기는 모델별 형태가 일정하기 때문에 충전식 전지의 사용이 가능하다. 그리고 고령자의 경우 전지의 교체 시 비용, 삽 입과 제거의 불편함 등으로 인해 충전식 보청기를 선택하는 경향 이 있다. 그러나 $\mathrm{CHA}$ 의 경우는 같은 형태 및 모델이라 하더라도 외이도의 형태에 따라 보청기의 모양이 달라지기 때문에 충전식 전지의 적용이 어려운 편이다. 그러나 최근 특정 회사에서는 충 전식 전지를 적용한 ITC를 출시하여 향후 $\mathrm{CHA}$ 보청기의 경우 도 충전식 전지의 적용이 가능할 것으로 보인다.

$\mathrm{RIC}$ 와 $\mathrm{CHA}$ 보청기의 선택 시 고려해야 할 기타 사항을 제조 기간 및 조절, 다른 기기와의 연결, 전화의 사용, 충전식 전지의 적용으로 구분하여 Appendix 3에 정리하였다.

\section{CONCLUSIONS}

본 연구에서는 외이도개방적합 보청기인 RIC와 외이도폐쇄적 합 보청기인 $\mathrm{CHA}$ 보청기의 효과적인 선택을 위하여 각 보청기 의 특징을 신체적인 특징, 음향 및 심리음향적 특성, 기타 고려사 항으로 구분하여 확인한 후 그 내용을 Appendix에 정리하였 다. 내용을 요약하면 RIC 보청기는 편안한 착용, 폐쇄효과의 감 소, 방향마이크로폰의 내장, 즉시 착용 및 조절, 손쉬운 다른 기 기와의 연결, 충전식 전지의 사용 등에 대한 장점이 있다. 그리고 $\mathrm{CHA}$ 보청기는 마스크의 착용, 일정한 삽입 위치, 음향피드백의 감소, 주파수반응곡선의 구현, 소음 하 어음청취능력, 적용 가능 한 청력역치의 범위, 전화의 사용 등에 있어서 장점이 있다.

보청기를 효과적으로 선택하기 위해서는 상기에서 기술한 내 용 외에 청각기관의 형태, 손의 민첩성, 시력 등 신체적인 요소, 생활환경, 나이, 보청기 착용 경험, 성격, 착용시간, 미적인 요소, 재정 및 직업 등 심리사회적인 요인, 주파수별 청력역치레벨과 음 량증가(loudness growth), 조용한 곳 및 소음 하에서의 어음인 지능력 등 청각적 요인, 보청기의 증폭특성, 형태, 조절 방법, 다 른 기기와의 연결 등 보청기의 특징을 고려하여야 난청인의 성공 적인 보청기 착용을 기대할 수 있다.

중심 단어: 보청기, 외이도개방적합, 외이도폐쇄적합, 외이도 내수화기, 귓속형보청기.

\section{Ethical Statement}

N/A 


\section{Acknowledgments}

N/A

\section{Declaration of Conflicting Interests}

There is no conflict of interests.

\section{Funding}

This research was completed while being supported by National Research Foundation of Korea (2018R1A2B6001986).

\section{Author Contributions}

Conceptualization: Sangyeon Lee, Kyoungwon Lee. Data curation: All authors. Formal analysis: All authors. Funding acquisition: Kyoungwon Lee. Investigation: Sangyeon Lee, Kyoungwon Lee. Methodology: All authors. Project administration: Kyoungwon Lee. Writing-original draft: Sangyeon Lee, Kyoungwon Lee. Writing_review \& editing: Soo Hee Oh. Approval of final manuscript: all authors.

\section{ORCIDiD}

Sangyeon Lee https://orcid.org/0000-0001-8401-5506

Soo Hee Oh https://orcid.org/0000-0002-3745-1484

Kyoungwon Lee https://orcid.org/0000-0002-1297-6436

\section{REFERENCES}

Aazh, H., Moore, B. C., \& Prasher, D. (2012). The accuracy of matching target insertion gains with open-fit hearing aids. American Journal of Audiology, 21(2), 175-180.

Anderson, B. \& Van Doorn, J. (2011). High Frequencies and Microphone Placement Lead to a New Type of RIC Hearing Aid. The Hearing Review. Retrieved from https://www.hearingreview.com/hearingproducts/hearing-aids/ite/high-frequencies-and-microphoneplacement-lead-to-a-new-type-of-ric-hearing-aid.

Başkent, D. (2006). Speech recognition in normal hearing and sensorineural hearing loss as a function of the number of spectral channels. The Journal of the Acoustical Society of America, 120(5 Pt 1), 2908-2925.

Caporali, S. A., Cubick, J., Catic, J., Damsgaard, A., \& Schmidt, E. (2019). The vent effect in instant ear tips and its impact on the fitting of modern hearing aids. Proceedings of the International Symposium on Auditory and Audiological Research (Proc. ISAAR), 7, 206-212.

Chalupper, J. \& Kasanmascheff, R. (2008, September 15). Maximizing Speech Intelligibility for Open Canal Fittings. AudiologyOnline. Retrieved from https://www.audiologyonline.com/articles/ maximizing-speech-intelligibility-for-open-906.

Dillon, H. (2012). Hearing Aids (2nd ed.). Stuttgart, NY: Thieme.

Froehlich, M., Giese, U., \& Powers, T. A. (2019, May 6). Why Open
Hearing Aid Fittings Are Often Not the Best Choice for the Patient. AudiologyOnline. Retrieved from https://www.audiologyonline. com/articles/why-open-hearing-aid-fittings-24982.

Froehlich, M. \& Littmann, V. (2019, May 21). Closing the Open Fitting: An Effective Method to Optimize Speech Understanding. The Hearing Review. Retrieved from https://www.hearingreview.com/ hearing-loss/patient-care/hearing-fittings/closing-open-fittingeffective-method-optimize-speech-understanding.

Galster, J. A. (2010). A new method for wireless connectivity in hearing aids. The Hearing Journal, 63(10), 36, 38-39.

Gnewikow, D. \& Moss, M. (2006). Hearing aid outcomes with openand closed-canal fittings. The Hearing Journal, 59(11), 66-72.

Groth, J. \& Mecklenburger, J. (2011, May 1). Dos and Don'ts of Open Fittings. The Hearing Review. Retrieved from https://www. hearingreview.com/practice-building/practice-management/dosand-donts-of-open-fittings.

Hoen, M. \& Fabry, D. (2007). Hearing aids with external receivers: Can they offer power and cosmetics? The Hearing Journal, 60(1), 28-34.

Jo, H., Kong, H., Shin, S., Lee, M., Kim, K., Lee, H., et al. (2021). Comparison of preferred real-ear insertion gain between open- and closed-canal fitting hearing aids. Audiology and Speech Research, 17(2), 180-186.

Kochkin, S. (2011). MarkeTrak VIII: Mini-BTEs tap new market, users more satisfied. The Hearing Journal, 64(3), 17, 18, 20, 22, 24.

Kuk, F. \& Baekgaard, L. (2008). Hearing aid selection and BTEs: Choosing among various "open-ear" and "receiver-in-canal" options. Hearing Review, 15(3), 22, 24, 26, 31, 32, 36.

MacKenzie, D. J. (2006). Open-canal fittings and the hearing aid occlusion effect. The Hearing Journal, 59(11), 50, 52, 54, 56.

Munro, K. J. \& Davis, J. (2003). Deriving the real-ear SPL of audiometric data using the "coupler to dial difference" and the "real ear to coupler difference". Ear and Hearing, 24(2), 100-110.

Needleman, A. R. \& Crandell, C. C. (1995). Speech recognition in noise by hearing-impaired and noise-masked normal-hearing listeners. Journal of American Academy of Audiology, 6(6), 414-424.

Park, J. \& Lee, K. (2019). Comparison of occlusion effect between ear-tip type of receiver-in-canal hearing aids and completely-in-the-canal. Audiology and Speech Research, 15(2), 95-100.

Prakash, S. G. R., Aparna, R., Kumar, S. R., Madhav, T., Ashritha, K., \& Navyatha, K. (2013). Sensori-neural hearing loss client's performance with receiver-in-canal (RIC) hearing aids. International Journal of Otolaryngology and Head and Neck Surgery, 2(2), 68-73.

Sanders, J., Stoody, T., Weber, J., \& Mueller, H. G. (2015). Manufacturers' NAL-nl2 fittings fail real-ear verification. Hearing Review, 21(3), 24.

Sim, S. \& Kim, J. (2019). The review of hearing aid satisfaction and market trends in the USA based on MarkeTrak. Audiology and Speech Research, 15(1), 11-22.

Teie, P. U. (2009, December 1). Ear-coupler Acoustics in Receiver-inthe-aid Fittings. The Hearing Review. Retrieved from https://www. hearingreview.com/practice-building/practice-management/earcoupler-acoustics-in-receiver-in-the-aid-fittings.

The Hearing Review. (2021, June 4). A Brief History of Hearing Aid Styles; 1991-2020. The Hearing Review. Retrieved from https:// www.hearingreview.com/hearing-products/hearing-aids/a-briefhistory-of-hearing-aid-styles.

Winkler, A., Latzel, M., \& Holube, I. (2016). Open versus closed hearingaid fittings: A literature review of both fitting approaches. Trends in Hearing, 20, 1-3. 


\section{APPENDIX}

Appendix 1. Considerations for selecting hearing aid between RIC and CHA types: physical characteristics

\begin{tabular}{|c|c|c|}
\hline & RIC(외이도내수화기) & $\mathrm{CHA}$ (귓속형 보청기) \\
\hline Cosmetics(미관) & $\begin{array}{l}\text { - 미관 상 좋음 } \\
\text { - 보청기몸체를 귓바퀴 뒤쪽 즉, 외이도 외부에 착용하기 노출 } \\
\text { 을 걱정하는 경우가 있음 } \\
\text { - 보청기몸체와 수화기를 연결하는 가는 전선이 타인에게 } \\
\text { 노출되는 것을 꺼려하는 경우가 있음 }\end{array}$ & $\begin{array}{l}\text { - CIC, IIC: 미관 상 좋음 } \\
\text { - ITE 및 ITC의 경우는 미관 상 싫어하는 } \\
\text { 경우가 있음 }\end{array}$ \\
\hline $\begin{array}{l}\text { Hearing aid wearing } \\
\text { (보청기의 착용) }\end{array}$ & $\begin{array}{l}\text { - 편안한 착용감 } \\
\text { - 손의 움직임이 둔한 경우 보청기몸체를 귓바퀴 뒤에 걸고, } \\
\text { 수화기를 외이도 내 정확한 위치에 넣는 것에 어려움이 있음 } \\
\text { - 마스크 착용 시 마스크 줄이 보청기 착용에 영향을 줄 수 } \\
\text { 있음 }\end{array}$ & $\begin{array}{l}\text { - 비교적 편안한 착용감 } \\
\text { - 손의 움직임이 둔한 경우 착용에 어려움 } \\
\text { 이 있음 } \\
\text { - 마스크 착용 시 마스크 줄이 보청기 착 } \\
\quad \text { 용에 영향을 주지 않음 }\end{array}$ \\
\hline $\begin{array}{l}\text { Small size of ear canal } \\
\text { (작은 외이도 직경) }\end{array}$ & $\begin{array}{l}\text { - 수화기를 정확한 위치에 삽입하는 데 어려움이 있어서 일정 } \\
\text { 한 이득과 음압을 제공하는 데 어려움이 있을 수 있음 } \\
\text { - 이어돔의 일그러짐으로 인한 폐쇄효과의 제거에 어려움이 } \\
\text { 있음 } \\
\text { - 폐쇄형 또는 이중 이어돔을 사용하는 경우 폐쇄효과의 해결 } \\
\text { 에 어려움을 줄 수 있음 }\end{array}$ & $\begin{array}{l}\text { - 항상 일정한 위치에 보청기를 삽입하여 } \\
\text { 일정한 이득과 음압을 제공할 수 있음 } \\
\text { - 작은 환기구로 인해 폐쇄효과의 해결에 } \\
\text { 어려움을 줄 수 있음 } \\
\text { - 폐쇄효과는 보청기를 꽉 차게 그리고 깊 } \\
\text { 게 삽입하여 폐쇄효과 해결이 가능 }\end{array}$ \\
\hline
\end{tabular}

RIC: receiver in-the-canal, CHA: custom hearing aid, CIC: completely in-the-canal, IIC: invisible in-the-canal, ITE: in-the-ear, ITC: in-the-canal

Appendix 2. Considerations for selecting hearing aid between RIC and CHA types: acoustic and electroacoustic characteristics

\begin{tabular}{|c|c|c|}
\hline & RIC(외이도내수화기) & $\mathrm{CHA}$ (귓속형 보청기) \\
\hline $\begin{array}{l}\text { Occlusion effect } \\
\text { (폐쇄효과) }\end{array}$ & $\begin{array}{l}\text { - 오픈 이어돔을 사용하는 경우 폐쇄효과의 해결에 } \\
\text { 효과적임 } \\
\text { - 이어돔이 일그러지는 경우 환기구의 변형으로 } \\
\text { 인해 폐쇄효과의 해결에 어려움이 있음 } \\
\text { - 청력역치의 상승으로 인해 폐쇄형 또는 이중 이어 } \\
\text { 돔을 사용하는 경우 폐쇄효과의 해결에 어려움이 } \\
\text { 있음 }\end{array}$ & $\begin{array}{l}\text { - 작은 직경의 환기구로 인해 폐쇄효과의 해결에 } \\
\text { 어려움이 있음 } \\
\text { - 보청기몸체(hearing aid shell)를 꽉 차게 그리고 } \\
\text { 깊게 삽입하여 폐쇄효과를 해결할 수 있음 }\end{array}$ \\
\hline $\begin{array}{l}\text { Acoustic feedback } \\
\text { (음향피드백) }\end{array}$ & $\begin{array}{l}\text { - 수화기와 마이크로폰의 간격이 멀어서 음향피드 } \\
\text { 백의 발생확률이 낮아짐 } \\
\text { - 개방형 이어돔의 경우는 큰 직경의 환기구로 인해 } \\
\text { 음향피드백의 발생확률이 높아짐 } \\
\text { - 음향피드백의 발생을 막기 위해 폐쇄형 또는 이중 } \\
\text { 이어돔을 사용하면 폐쇄효과가 증가할 수 있음 }\end{array}$ & $\begin{array}{l}\text { - 수화기와 마이크로폰의 간격이 가까워서 음향피드 } \\
\text { 백의 발생확률이 높아짐 } \\
\text { - 보청기몸체의 작은 직경의 환기구로 인해 음향피 } \\
\text { 드백의 발생확률이 낮아짐 }\end{array}$ \\
\hline $\begin{array}{l}\text { Frequency response } \\
\text { curve(주파수반응곡선) }\end{array}$ & $\begin{array}{l}\text { - 저/고주파수의 이득을 제공하는 데 어려움이 있음 } \\
\text { - 음질, 어음인지도, 만족도 등에 영향을 줄 수 있음 }\end{array}$ & $\begin{array}{l}\text { - 보청기적합공식에서 산출한 주파수반응곡선을 } \\
\text { 제공하는 데 유리함 }\end{array}$ \\
\hline $\begin{array}{l}\text { Speech perception in } \\
\text { noise(소음 하 어음청취 } \\
\text { 능력) }\end{array}$ & $\begin{array}{l}\text { - 큰 환기구로 인해 소음 하에서의 어음인지능력이 } \\
\text { 저하될 수 있음 } \\
\text { - 저주파수 대역의 청력역치가 좋은 경우 주변의 소 } \\
\text { 음이 어음의 인지에 악영향을 줄 수 있음 }\end{array}$ & $\begin{array}{l}\text { - RIC에 비해 주변 소음의 영항이 적음 } \\
\text { - 저주파수의 청력역치가 좋더라도 어음의 인지에 } \\
\text { 있어서 소음의 영향이 적음 }\end{array}$ \\
\hline $\begin{array}{l}\text { Directional } \\
\text { microphone(방향마이 } \\
\text { 크로폰) }\end{array}$ & $\begin{array}{c}\text { - 두 개의 마이크로폰에서 음입구(inlet) 간의 거리 } \\
\text { 확보가 가능하여 방향마이크로폰의 내장이 가능 }\end{array}$ & $\begin{array}{l}\text { - } \mathrm{CIC} \text { 또는 IIC의 경우 두 개의 마이크로폰에서 음 } \\
\text { 입구 간의 간격 확보가 어려워 방향마이크로폰의 } \\
\text { 내장이 어려움 } \\
\text { - ITE 또는 ITC의 경우는 방향마이크로폰의 내장이 } \\
\text { 선택적으로 가능 } \\
\text { - 귓바퀴가 방향마이크로폰의 역할을 할 수 있음 }\end{array}$ \\
\hline $\begin{array}{l}\text { Applicable hearing } \\
\text { threshold level(적용 가 } \\
\text { 능 청력역치) }\end{array}$ & $\begin{array}{l}\text { - 중·고주파수 대역의 청력역치가 } 60 \sim 70 \mathrm{~dB} \mathrm{HL} \text { 이 } \\
\text { 상인 경우 음향피드백의 영향으로 사용에 제한이 } \\
\text { 있음 } \\
\text { - 음향피드백의 영향으로 폐쇄형 또는 이중 이어돔 } \\
\text { 을 사용하는 경우 폐쇄효과의 해결이 어려울 수 } \\
\text { 있음 }\end{array}$ & $\begin{array}{l}\text { - 청력역치가 높은 경우에도 사용이 가능 } \\
\text { - 형태가 작은 CIC의 경우 RECD를 활용하면 심한 } \\
\text { 청력손실자도 착용이 가능 }\end{array}$ \\
\hline
\end{tabular}

RIC: receiver in-the-canal, CHA: custom hearing aid, CIC: completely in-the-canal, IIC: invisible in-the-canal, ITE: in-the-ear, ITC: in-the-canal, RECD: real-ear to coupler difference 
Appendix 3. Considerations for selecting hearing aid between RIC and CHA types: additional aspects

\begin{tabular}{|c|c|c|}
\hline & RIC(외이도내수화기) & CHA(귓속형 보청기) \\
\hline $\begin{array}{l}\text { Production period \& fitting } \\
\text { (제조 기간 및 조절) }\end{array}$ & $\begin{array}{l}\text { - 이어돔을 크기별로 갖추면 별도의 제작 } \\
\text { 기간이 필요 없어서 즉시 착용, 조절 } \\
\text { 및 판매가 가능함 }\end{array}$ & $\begin{array}{l}\text { - 접수 및 발송 기간을 포함하여 } 1 \text { 주일 내외의 제작 기간이 } \\
\text { 필요 } \\
\text { - 따라서 즉시 착용, 조절 및 판매가 어려움 }\end{array}$ \\
\hline $\begin{array}{l}\text { Connection to other } \\
\text { devices(다른 기기와의 연결) }\end{array}$ & $\begin{array}{l}\text { - 블루투스 또는 기타 무선 안테나의 내 } \\
\text { 장이 가능하여 다른 기기와의 연결이 } \\
\text { 손쉬움 }\end{array}$ & $\begin{array}{l}\text { - 블루투스 또는 무선 안테나의 내장이 어려워서 다른 기기 } \\
\text { 와의 연결이 어려움 } \\
\text { - ITE, ITC에는 안테나의 내장이 가능 } \\
\text { - 최근에 CIC에도 안테나를 내장하는 경우가 있지만 보청 } \\
\text { 기의 크기가 커질 우려가 있음 }\end{array}$ \\
\hline Phone usages(전화의 사용) & $\begin{array}{l}\text { - 마이크로폰이 귓바퀴 뒤에 착용하는 } \\
\text { 보청기몸체에 위치하기 때문에 전화 } \\
\text { 통화 시 주의가 필요 }\end{array}$ & $\begin{array}{l}\text { - 음향피드백이 발생하지 않는 경우 건청인과 비슷한 형태 } \\
\text { 로 전화 통화가 가능 }\end{array}$ \\
\hline $\begin{array}{l}\text { Rechargeable battery(충전식 } \\
\text { 전지) }\end{array}$ & $\begin{array}{l}\text { - 모델이 같은 경우는 보청기의 형태가 } \\
\text { 같기 때문에 충전식 전지의 적용이 가능 }\end{array}$ & $\begin{array}{l}\text { - 같은 모델의 경우에도 외이도의 형태에 따라 보청기의 } \\
\text { 모양이 다르기 때문에 충전식 전지의 적용이 어려움 } \\
\text { - 최근에 충전식 전지를 사용할 수 있는 CHA (ITC 등)를 } \\
\text { 출시하기 시작하였음 }\end{array}$ \\
\hline
\end{tabular}

RIC: receiver in-the-canal, CHA: custom hearing aid, ITE: in-the-ear, ITC: in-the-canal, CIC: completely in-the-canal 